\title{
Geochemical survey and evaluation excavations at Alderley Edge: recognising anthropogenic signatures within a mining site-scape
}

Christopher J. Carey

Norman R. Moles

\begin{abstract}
:
Archaeological science and field investigations are making greater use of multi-element geochemical survey as a tool for site prospection and intra-excavation analysis. This increasing use of geochemical survey is allowing a new field of geoprospection to develop, a technique that has specific relevance to the investigation of sites containing archaeometallurgical evidence, due to the high geochemical loadings within archaeological contexts produced from past metalworking activities. Correspondingly, there have been relatively few published examples that compare the results of geochemical surveys against excavation data. This study reports the use of geochemical data to investigate a multi-period mining site-scape at Alderley Edge, Cheshire, UK. The geochemical data is analysed using Principle Components Analysis, which facilitates the identification of a number of geochemical anomalies. The site taphonomy and stratigraphic evolution of this mining site-cape is complex, with naturally occurring areas of lead and copper mineralisation and a history of exploitation since the early Bronze Age. The geochemical anomalies were compared to the results of excavation within the survey area and this combination of excavation and prospection data allowed the reasons for the different geochemical anomalies to be explained. The paper highlights the potential of using multi-element geochemical survey to investigate sites containing archaeometallurgical remains and provides a discussion of why context specificity is essential to correctly interpret multi-element geochemical data.
\end{abstract}

Key words: Geochemical survey, Archaeometallurgy, GIS, Context Specificity, Alderley Edge, Mining 


\section{Introduction}

Archaeology has developed many forms of prospection through which archaeological sites and features can be mapped, such as gradiometer survey, earth resistance survey, magnetic susceptibility survey and ground penetrating radar (Clark 1997; Gaffney and Gaiter 2003; Gaffney 2008). Such methods have a proven track record of defining features and relating these features to changes in physical phenomena such as resistance or magnetic measurements. A technique of survey/prospection that is seeing increasing application within archaeological investigations is geochemical survey, with many researchers taking advantage of the ability of multi-element analyses to investigate anthropogenic geochemical signatures within archaeological soil/sediment systems (Wilson 2008; Canti and Huisman 2015, 100 - 102).

Unlike more established forms of archaeological geoprospection, geochemical survey has not yet become a mainstream archaeological tool, and can still be considered to be within a development phase, rather than a robust tool of archaeological scientific analysis. The development of geochemical survey has witnessed a diverse range of surveys undertaken through the investigation of archaeological and ethnographic sites, for a range of different human activities. Examples include landscape scale habitation signatures (Entwistle et al. 2000); landscape scale metal pollution signatures (Grattan et al. 2007); identification of habitation sites in Greece (James, 1999); geochemical signatures across prehistoric mining landscapes (Jenkins et al. 2001); identifying fish subsistence camps and activity areas in arctic soils (Knudson et al. 2004); analysis of activity areas within archaeological sites (Parnell et al. 2002); identification of ethnographic activity areas within houses (Middleton and Price 1996), identification of activity areas (anthrosols) within archaeological site sequences (Vittori et al. 2013), identifying former habitation signatures within settlements (Wilson et al. 2009) and as a tool of intra-excavation analysis identifying Romano British metalworking (Cook et al. 2005).

There can be considered to be two types of geochemical survey: prospection and analysis. Firstly, a prospection survey can be used to find geochemical residues that indicate anthropogenic activity, even if the process that caused the deposition of these residues is unknown, e.g. Bintliff et al. (1992) to locate settlement sites, with Dirix et al. (2013) suggesting that geochemical survey can be employed to complement conventional magnetic survey data and interpretation in prospection surveys. Secondly, there is the application of geochemical survey to identify residues that are caused through (and can define) a specific human activity, e.g. deposition of $\mathrm{Cu}$ from metalworking, i.e. intra-site analysis e.g. Carey et al. (2014). These two types of geochemical survey are not mutually exclusive, but they do apply a different rationale for undertaking the survey in the first place. There is also a significant difference in how the transfer function of the proxy (geochemistry) to human activity is interpreted.

A critical factor related to these uses of geochemical survey is the scale of application and whether geochemical survey is best suited as site prospection tool (Aston et al. 1998); a method of inter-site comparison (Oonk et al. 2009); as a method of intra-site analysis (Milek and Roberts 2013) or as a method of intra-excavation analysis (Cook et al. 2010; Carey and Juleff 2013). Whilst it is not intended to critique the relative merits (and failures) of different scales of application for geochemical survey, it can be argued that geochemical surveys that have been applied on an intra-site and/or context specific basis have had considerable success in interpreting geochemical residues in relation to specific 
human activities and behaviours, e.g. Cook et al. (2010) and Conway (1983). In general, the scale of application and underlying rationale for undertaking a geochemical survey has lacked critical debate within the archaeological literature.

Some researchers have argued for the importance of context specificity with archaeological geochemistry (Davis et al. 2012), treating geochemical residues as artefacts in their own right (Carey et al. 2014). If this position is accepted, that geochemical residues are direct markers of past human activities similar to other materials sampled through excavation, e.g. charred plant remains, pottery, etc, then the scale of application becomes more relevant. If there is a direct linkage between geochemical residues and specific human activities defined by archaeological context, then the scale of the survey is limited to the area of excavation, i.e. where contexts are recognised and sampled. Nowhere is this more applicable than when using geochemical survey to investigate archaeological sites containing evidence of metalworking, where contexts from metallurgical activities are liable to have very high geochemical loadings (Carey and Juleff 2013). However, it could be questioned whether geochemical data should be treated as equivalent to artefacts created by past human activity, which leads to questioning whether geochemical data does hold most value as context specific data? Even if geochemical data does hold most value as context specific data, does non context specific geochemical data still have interpretable archaeological value, analogous to retrieving artefacts during field walking? This issue of context specificity is critical to how archaeologists apply geochemical survey and what questions they ask of the data, and this study presented here contributes to this debate.

This paper presents the results of geochemical survey within part of a mining landscape within Alderley Edge, Cheshire, UK (Figure 1). This survey was undertaken as a method of intra-site prospection, to identify geochemical anomalies that could be indicative of prehistoric mining activity, with Alderley Edge containing a copper ore source that was exploited from the early Bronze Age, $c$. 2000 BC (Timberlake and Pragg 2005). The results from this survey were used to help inform the location of excavation trenches, as part of a wider site management and investigation plan. This research investigates the application of geochemical survey and how the results from a surface geochemical survey relate to the evaluation excavation results. These data are used to further discussion on the importance of context specificity of geochemical data, and highlight the difference between aspects of surface geochemical anomalies and sub-surface archaeological features. This survey also has value in adding to the discussion of the use of geochemical survey to identify evidence of past metalworking.

\section{Introduction to the study area: Alderley Edge geology and mining}

Alderley Edge is an escarpment of sandstone rising above the Cheshire plain, UK, with the geology and mineralization of the ridge most comprehensively described by Carlon (1979). The bedrock comprises conglomerates, sandstones and marls of Triassic age, which were deposited in an arid terrestrial environment by intermittently flowing rivers and aeolian processes. Outcropping on the crest of the ridge at Stormy Point and Castle Rock are the Engine Vein Conglomerates which comprise interbedded pebbly conglomerates and coarse sandstone beds. Beneath this is the Upper Mottled Sandstone which comprises interbedded fine-grained sandstones and thin marl beds (calcareous siltstones). The 
strata dip gently to the southwest and are displaced by a series of east-west to north-south oriented faults.

Commonly the faults acted as channels for the migration of hydrothermal fluids and are mineralized with baryte (barium sulphate) and galena (lead sulphide). Baryte, together with a variety of copperand cobalt-bearing minerals, occur within the conglomerates and sandstones as bedding-parallel disseminations, pore-filling cements, veinlets and nodules. The most common copper mineral is malachite (a green hydrous carbonate); less frequent are azurite (blue hydrous carbonate) and chrysocolla (green siliceous gel). The lead carbonate cerussite and yellow-green lead chlorophosphate pyromorphite also occur as disseminations and nodules within sandstone close to faults such as at the Engine Vein Mine, Stormy Point. The mineralized sandstones have a bleached appearance due to the removal of iron oxides by hydrothermal fluids. Black spots, streaks and veins of complex manganese-rich 'wad' and cobalt-rich 'asbolane' also occur in the sandstones spatially associated with malachite.

These mineral deposits, containing both copper and lead, were mined from the Early Bronze Age $c$. $2000 \mathrm{BC}$ ), through to the Post Medieval period, producing an important heritage mining landscape, both above and below ground. The archaeological investigation of the Alderley Edge mines initially occurred in a piecemeal fashion, although there was an early (19 $9^{\text {th }}$ century) indication of the possible prehistoric origins to the mining. Early excavations revealed hammerstones and a wooden shovel around 'old diggings', both types of evidence realised to indicate prehistoric metalworking (Sainter 1878; Boyd Dawkins 1876). The rescue and dating of the wooden shovel in 1993 revealed a Bronze Age date for the shovel (1888-1677 Cal BC; Garner et al. 1993) and helped inspire a concerted phase of archaeological investigation into Alderley Edge, with further evidence of prehistoric mining being found as pit workings dating to the early Bronze Age (Timberlake and King 2005). A later Roman mine shaft was also discovered containing a votive Roman coin hoard dated to the fourth century $A D$ (Timberlake and Kidd 2005). No evidence of mining between the Roman period and the late seventieth century has been revealed, but documentary sources indicate mining started again in 1690, reaching a peak in the 1870s before finally dying out in 1919 (Timberlake and Pragg 2005). These later phases of mining have had a significant impact on destroying and disguising evidence for earlier phases of mining activity.

\section{Justification of materials and methods}

The geochemical survey was undertaken before the excavation, in order to use the results from the geochemical survey to locate areas of archaeological interest for evaluation trenching. Consequently, the geochemical survey was a surface survey, undertaken prior to excavation, meaning the geochemical readings were not context specific at the time of survey.

The geochemical survey had the following aims:

- To assess the geochemical distributions across the survey area.

- To characterise the bedrock geochemistry within the survey area, as source inputs into the soil/sediment systems. 
- To identify any anthropogenically derived geochemical loadings, either through spatial patterning and/or introduction of non-native elements to the survey area.

The results from the geochemical survey contributed to the siting of excavation trenches. The excavation trenches aimed to:

- Quantify/qualify the state of preservation of any archaeological deposits.

- Define the depths of intact archaeological stratigraphy across the site.

- Identify archaeological structures and previous human activities (e.g. ore processing) within the survey area.

- Characterise the physical matrix of the archaeological contexts (which could later be related to the geochemical survey results).

\section{Materials and methods}

A Portable X-Ray Fluorescence spectrometer (PXRF) was used to obtain in-situ geochemical data from the study area. The advantages of using a PXRF for this type of survey include non-intrusive survey with minimal disturbance, no removal of samples and low analytical costs. The instrument deployed was an Innov-X Alpha Series ${ }^{\text {TM }}$ PXRF manufactured in 2004. The X-ray source is a battery-powered, 35 $\mathrm{keV}, \mathrm{Ag}$ anode x-ray tube. Detection limits are in the order of 1-5ppm for heavy elements and 10$50 \mathrm{ppm}$ for lighter metals. The instrument employs a calibration system (Compton Normalisation) which enables element content to be measured over a wide range of concentrations (tens of parts per million to tens of percent), and corrects for a variety of matrix interference effects. Trials with this instrument using Certified Reference Materials (CRMs) of metal-enriched silicate sediments found no evidence of interference due to overlapping fluorescence ( $\mathrm{Pb}-\mathrm{As}, \mathrm{Cu}-\mathrm{Zn}, \mathrm{Mn}-\mathrm{Fe}$ ) or matrix effects ( $\mathrm{Zr}$ $\mathrm{Sr}$ ). It was concluded that the factory-installed calibrations are excellent for most elements investigated within the compositional range of the CRMs investigated. However the calibrations may become inappropriate when materials of widely differing heavy metal composition/concentrations

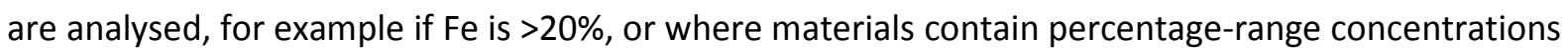
of heavy elements such as $\mathrm{Ba}$ or $\mathrm{Pb}$.

Both Killick (2015) and Torrence et al. (2015) warn of the use of pXRF in archaeological investigations, and the lack of consistency between different surveys and instruments. Within this study the data was used for intra-site analysis only. The true values of elements within the samples were less important than the relative change between samples. In this sense, the data from this study is not being used to compare to other data, from other studies, using different instrumentation, but instead it is used as a method of intra-site analysis. However, the use of CRMs have helped create a data set that has within survey standardisation.

At each sample location, an area of approximately $80 \mathrm{~mm}$ by $30 \mathrm{~mm}$ was cleared of surface deposits to a depth of a $2 \mathrm{~cm}$, so that the $12 \mathrm{~mm}$ diameter analysis window of the PXRF could be placed in direct contact with the ground surface. At sampling locations where visually heterogeneous material was encountered, a volume of approximately $80 \mathrm{~mm}$ by $80 \mathrm{~mm}$ by $20 \mathrm{~mm}$ deep was mixed and multiple measurements were averaged to ensure a representative result. In total 193 measurements were collected at 178 locations across an area of approximately $45 \mathrm{~m}$ by $25 \mathrm{~m}$, elongated NW-SE. Most 
sample locations are on NW-SE transects with a spacing of $1.0 \mathrm{~m}, 1.5 \mathrm{~m}$ or $2.0 \mathrm{~m}$, providing a density of typically 1 per $2 \mathrm{~m}^{2}$ increasing to 1 per $1 \mathrm{~m}^{2}$ in areas of particular interest. The shape of the surveyed area is irregular, corresponding to the area of exposed soil and 'mining spoil' material and marl bedrock. It is bounded almost entirely by areas of sandstone bedrock, except to the southeast where a fence delimited the exposed area. Two transects extend outside the central area; one along the base of the conglomerate bluff at the southwest edge of the site, and the other along the path extending southeast, on the northeast side of the bounding fence. As the difference between geochemical readings from bedrock and sediments could be substantial, and provide a significant leverage on any subsequent data analysis, a record was made of the substrate sampled and labelled as either exposed Asbolane, Marl Green, Marl Red, Sandstone, Ore (areas of sediment with a high ore/ore detritus content in the matrix, although this had been redeposited through either human or natural agency) and sediment.

The data processing sorted the raw geochemical data. Some of the elements reported were mostly at concentrations close to or below detection levels. These elements were removed from the processed dataset leaving reliable data for $\mathrm{Ti}, \mathrm{Mn}, \mathrm{Fe}, \mathrm{Ni}, \mathrm{Cu}, \mathrm{Pb}, \mathrm{Zn}, \mathrm{Ag}, \mathrm{Ba}, \mathrm{Rb}, \mathrm{Sr}, \mathrm{Zr}$ and $\mathrm{As}$. The inclusion of bedrock analyses provided leverage on the data set, influencing the position of the new principle components towards element groupings associated with the bedrock geologies, so two separate analyses were undertaken. The first level of analysis included all of the samples in the database and is called the Complete Dataset Analysis. This dataset allowed the geochemistry of the soils and sediments to be related to the geological readings. The second level of analysis focused on the soils and sediments within the survey area, with the bedrock analyses removed. This second level of analysis is called the Sediment Only Analysis. This level of analysis allowed the geochemistry to be investigated within the sediments forming the physical archaeological record. The utilisation of this two tiered analysis facilitated investigation of the relationship between local bedrock geochemistry and the transfer of metals into the archaeological sediment matrix.

Both levels of analysis utilised simple univariate descriptive statistics, as well as dimensionality reduction through a Principle Components Analysis (PCA) using SPSS (ver22). The PCA used a correlation matrix and the principle component factor loadings were saved. The application of PCA and plotting of the subsequent factor scores has been previously used to define geochemical signatures related to human activities (e.g. Carey et al. 2014; James 1999; Linderholm and Lundberg 1994). Whilst the use of single element plots is useful, it often produces a mass of conflicting data that is difficult to reconcile. PCA removes some of this ambiguity through identifying signatures and reducing the importance of uncorrelated element data from the spatial analysis. All the data from the site investigation, geochemical survey and data analysis were entered into a GIS system (ARCMAP ver. 10.3), with each original sample location containing the univariate geochemical data and the factor loading for each principle component. The utilisation of PC factor scores allowed the contribution of each sample to the positioning of the new principle components to be modelled, allowing areas (samples) of high geochemical correlation and enhancement to be identified. These data were converted into interpolated maps via a Kriging function, with key anomalies identified and related to the position of the excavation trenches.

\section{Results: Complete Dataset Analysis}


The Complete Dataset Analysis demonstrated the presence of geological readings within the survey area that showed significantly elevated levels of $\mathrm{Cu}, \mathrm{Pb}, \mathrm{Zn}$ and $\mathrm{As}$ (the Green and Red Marls, Sandstone and Ore categories). The presence of asbolane was characterised by elevated levels of $\mathrm{Ni}$ and to a lesser extent $\mathrm{Ag}, \mathrm{Pb}$ and $\mathrm{Mn}$. The sediment samples displayed elevated levels of $\mathrm{Pb}, \mathrm{Ag}$ and $\mathrm{Mn}$ that were above the average mean bedrock levels for marls and sandstone but below the ore and asbolane mean concentrations. However, this situation is reversed for $\mathrm{Fe}, \mathrm{Zn}$ and $\mathrm{Cu}$, with the bedrock and ore all displaying higher concentrations compared to the sediment (Figure 2).

Significantly, the red and green coloured marls were shown to be geochemically very similar. The colour difference is inferred to be caused by the oxidation state of iron, i.e. predominantly $\mathrm{Fe}^{3+}$ in red marls and $\mathrm{Fe}^{2+}$ in green marls. Figure 2 clearly demonstrates that both the ore and sediment averages revealed higher values for $\mathrm{Cu}, \mathrm{Pb}, \mathrm{As}, \mathrm{Ag}$ and $\mathrm{Ba}$, although widely different population sizes for each substrate type means that significant testing is a not a valid option for these sample populations.

These univariate descriptive analyses demonstrate that the bedrock, ore and sediment samples display different concentrations of similar elements. The difference between the bedrock samples and the sediment samples does not necessarily indicate human agency, it could simply be a variation of source material feeding into a soil/sediment system. The PCA analysis of the Complete Dataset Analysis extracted three components with an eigenvalue over 1 . The relationship of the original variables is shown against $\mathrm{PCl}$ and $\mathrm{PCll}$ (Figure 3), with the component loadings for $\mathrm{PCl}$ and $\mathrm{PCll}$ displayed as interpolated plots (Figures 4 and 5).

The positioning of $\mathrm{PCl}$ is strongly influenced by $\mathrm{Ba}, \mathrm{Pb}, \mathrm{Ag}$ and $\mathrm{Sr}$, and to a lesser extent $\mathrm{As}$. This principle component would seem to relate to the strong inter-variable correlations found in some of the geological samples. The $\mathrm{Pb}-\mathrm{Ag}$-Ba-Sr group indicates a galena-baryte association in the bedrock geochemistry, with minor $\mathrm{Ag}$ associated with galena and minor Sr occurring in baryte. PCII was strongly influenced by $\mathrm{Ti}, \mathrm{Fe}, \mathrm{Rb}$ and $\mathrm{Zn}$ indicating 'lithophile' elements associated with rock-forming oxides and silicates. The absence of significant correlations between $\mathrm{Cu}$ and $\mathrm{Pb}$, and between $\mathrm{Cu}$ and $\mathrm{Ba}-\mathrm{Sr}$, correspond to the disassociation of these elements in the local bedrock and suggest that they are derived from different materials.

The spatial patterning of the $\mathrm{PCl}$ from the all data analysis defines anomaly 1 at trench 1 and anomaly 2 at trench 10 (Figure 4). The position of PCll was strongly influenced by $\mathrm{Fe}, \mathrm{Zn}$ and Ti, and to a moderate extent $\mathrm{Cu}$ and $\mathrm{Pb}$. The spatial plotting of the $\mathrm{PCll}$ factor scores produces anomaly 3 , which is produced from several sediment samples (Figure 5). This anomaly has significance for the interpretation of the excavation data, but is more visible in the sediment samples only data (below) and is close to trench 6 . Anomaly 4 is also visible in this plotting of the PCII factor scores and is located at trench 8 .

\section{Results: Sediment Only Analysis}

The Sediment Only Analysis used readings only from sediment samples, with the samples of Marl Green, Marl Red, Absolene, Ore Geology and Sandstone removed. The formation of archaeological contexts is derived from sediments, although within a mining landscape some of these sediments could be redeposited and processed bedrock. The Sediment Only Analysis defined four new 
components with an eigenvalue over 1 , potentially indicating a higher degree of 'geochemical signatures' within the sediment samples. The PCl from the Sediment Only Analysis was strongly influenced by $\mathrm{Fe}, \mathrm{Zn}, \mathrm{Pb}$ and $\mathrm{As}$, with a lower level of positive association with $\mathrm{Ag}$. This should be compared to $\mathrm{PCl}$ of the entire data analysis, where $\mathrm{PCl}$ was strongly associated with $\mathrm{Ba}, \mathrm{Pb}, \mathrm{Ag}$ and $\mathrm{Sr}$, and to a lesser extent As. In effect, the removal of the geological samples has produced a repositioning on the first principle component. The positioning of PCII was strongly influenced by Ba and Sr. PCIII was primarily influenced in its positioning by $\mathrm{Cu}$ (Figure 6).

The spatial interpolation of the factor scores shows a series of distinct anomalies, with $\mathrm{PCl}$ defining anomaly 5, located at trenches 4 and 8 , whilst anomaly 6 is located at trench 6 (Figure 7). The spatial plotting of PCII revealed anomaly 7, which produces a further anomaly in the vicinity of trench 6 (Figure 8). The absence of a corroborative anomaly for anomaly 1 at trench 10, from the Complete Dataset Analysis PCA, is explained by the removal of the bedrock samples.

\section{Results: Relating geochemical anomalies to excavation data}

The Complete Dataset Analysis PCA and the Sediment Only Analysis PCA have revealed a series of anomalies from the plotting of the PCA factor scores. The removal of the geological samples has unsurprisingly revealed different groupings of elements between the levels of analysis. A summary of this analysis is:

- $\mathrm{PCl}$ from the Complete Dataset Analysis identified anomaly 1 at trench 1 and anomaly 2 at trench 10 , with the position of $\mathrm{PCl}$ heavily influenced by $\mathrm{Ba}, \mathrm{Pb}, \mathrm{Sn}, \mathrm{Ag}$ and $\mathrm{Sr}$, and to a lesser extent As.

- PCll from the Complete Dataset Analysis identified anomaly 3 close to trench 6 and anomaly 4 at trench 8 , with the position of PCII heavily influenced by Fe, $\mathrm{Zn}$ and $\mathrm{Ti}$.

- PCI from the Sediment Only Analysis identified anomaly 5 at trenches 4 and 8 , and anomaly 6 at trench 6 .

- PCII from the Sediment Only Analyses produces anomaly 7 in the vicinity of trench 6 .

- There is a strong spatial correlation between anomalies 3 (PCII Complete Dataset Analysis), 6 (PCl Sediment Only Analysis) and anomaly 7 (PCII Sediment Only Analysis).

- When the geological samples were included in the analysis they had a considerable influence of the positioning of the principle components.

- The univariable analysis of individual elements produced a mass of potentially conflicting results, which the PCA has clarified and identified distinct geochemical signatures.

Of critical importance to this study is the relationship of the identified geochemical anomalies to the excavation data and as such the most significant findings from the excavation trenches will be discussed relative to the geochemical survey results. Anomaly 1 was located close to trench 1 . This trench contained contexts (006), (007), (014) and (015), all of which are interpreted as probable mining upcast deposits, which are clay dominated, probably removed from between the bedding planes of the bedrock, to allow exploitation of nodules of malachite and azurite (Figure 9). Context (001) is at the surface of the trench and is a brown compact silty sand of colluvial origin that was directly analysed by the PXRF analysis, although one of the readings in this area sampled a piece of ore within (001). Anomaly 1 was defined by the Complete Dataset Analysis, with the location of $\mathrm{PCl}$ heavily influenced 
by with $\mathrm{Pb}, \mathrm{Ag}, \mathrm{Ba}, \mathrm{Sr}$ and As. As anomaly 1 was most heavily influenced by a single sample analysis of ore geology within context (001), it would seem probable that anomaly 1 does not relate to subsurface mining upcast, but a washed in piece of ore in the colluvial layer (001). Consequently, there is no definable relationship between anomaly 1 and the deposits of mining upcast beneath the colluvium in trench 1.

Anomaly 2 was also identified by PCl factor scores of the Complete Dataset Analysis and was partly investigated through trench 10 . The excavation revealed that contexts $(079) /(084)$ were dump deposits containing clay and galena. This deposit was adjacent to [083], a possible cut bowl feature of anthropogenic origin. The galena and clay found within contexts $(079) /(084)$ were discoloured by heating or chemical processes (although no charcoal was identified in this context) and outcropped at the surface of the trench (Figure 9). Anomaly 2 was identified by PCl in the Complete Dataset Analysis and was associated with $\mathrm{Pb}, \mathrm{Ag}, \mathrm{Ba}, \mathrm{Sr}$ and $\mathrm{As}$ and can be related to contexts $(079) /(084)$, given the relationship of $\mathrm{PCl}$ to $\mathrm{Ag}$ and $\mathrm{Pb}$. The interpretation of this deposit during excavation was an imported material probably from another mining area associated with ore processing. Given that this context outcrops at the surface, the geochemical survey has successfully identified mining detritus at this location.

Anomalies 3 and 6 were located close to trench 6 . Anomaly 3 was determined by PCII of the Complete Dataset Analysis, showing a strong relationship to Fe, $\mathrm{Zn}$ and Ti, with anomaly 6 defined by PCII of the Sediment Only Analysis heavily influenced by $\mathrm{Fe}$ and $\mathrm{Zn}$, and to a lesser extent $\mathrm{Ti}$ and $\mathrm{Ni}$. Trench 6 revealed a shallow bowl cut [046] into the bedrock, infilled with contexts (125), (049) and (050), inwashed sandstone contexts. Above feature [046] were a series of colluvial inwash, sand dominated deposits (116), (121), (128) and (127). At the top of the sequence were contexts (117), (118) and (119) that are also colluvial derived, but which contained a large volume of pre-industrial iron smithing slag and hammerscale. Context (118) contained iron slag that is possibly part of a smithing hearth base, although on excavation the identification of a hearth was not definitive (Figure 10). Critically at this location contexts (117), (118) and (119) were surface deposits and these were sampled by the geochemical survey. At this location, anomalies 3 and 6 are clearly defining ironworking, identified by PCII in both levels of analysis. The size of both of these anomalies indicates a substantial deposit of ironworking material, although the actual extent and volume of the ironworking at the site is unknown, due to the limited size of the trench at this location.

Anomaly 4 was located at trench 8 and was identified by the PCIl factor scores from the Complete Dataset Analysis associated with $\mathrm{Ti}, \mathrm{Mn}, \mathrm{Fe}, \mathrm{Ni}, \mathrm{Cu}, \mathrm{Pb}$ and $\mathrm{As}$, and also by anomaly 5 from $\mathrm{PCl}$ of the Sediment Only Analysis associated with $\mathrm{Pb}, \mathrm{Cu}, \mathrm{Ag}, \mathrm{Ba}$ and $\mathrm{Sr}$. On excavation trench 8 was shown to have a single fill deposit sequence consisting of context (130) beneath a very thin layer of colluvium (129), which was cleared away during the PXRF analysis, allowing measurement of context (130) (Figure 10). Context (130) was shown to be a mixed single fill deposit, interpreted as a foreign soil collected and brought onto the site to fill one of the holes left by mining activity, although there is a supposition that the material was imported from another mining/ore processing area close to the site (Mottershead and Wright, 2008, 28). This foreign material has a different geochemical signature to the rest of the survey area, and was identified as anomaly 4 by the geochemical survey.

Anomaly 5 defined from the $\mathrm{PCl}$ factor scores of the Sediment Analysis Only covered trenches 8 (described above) and also trench 4 . PCl from this level of analysis had strong positive association to 
$\mathrm{Ag}, \mathrm{Pb}, \mathrm{Ba}$ and $\mathrm{Sr}$, but also a moderately strong positive association with $\mathrm{Cu}$. The excavation of trench 4 revealed a complex stratigraphy associated with an Early Bronze Age pit and associated fill sequence (Figure 11). Context (170) is notable, containing a charcoal rich leached grey fine sand, interpreted as the remains of a fire, and (168), a grey brown silty fine sand and abundant sub-angular sandstone. Context (168) is interpreted as a deliberate backfill and provided a charcoal AMS date of 1690-1510 BC (95.4\% probability; SUERC-17840 (GU-16448)). Interestingly, all of the contexts in the [167] fill sequence ((168), (169), (170) and (171)) contained hammerspall, which are small stone flakes removed from the ore and are indicative of ore processing.

This phase of Bronze Age activity (probably ore processing within a pit, rather than mining per se) had been truncated by cut [165], which contained the fills (164), (166), (172), (173) and (174). Contexts (174), (173) and (172) were all inwash layers dominated by fine sand. Above this context (166) was another deliberate backfill layer with fine brown silty sand and abundant subangular sandstone clasts. This fill sequence is undated and the function is unknown, but none of the contexts in the [165] fill sequence contained hammerspall, indicating they are not directly associated with ore processing. This fill sequence was truncated by another cut [151], which contained a deposit sequence of colluvial inwash sands (163), (162), (161), (160) and (159). Context (158) seals this sequence and is interpreted as a recent (post medieval) mixed dump of material foreign soil to the site-scape including sand, sandstone fragments, Yorkshire fog grass (still green) and a cigarette filter tip. Above this are a series of inwash colluvial sands, contexts (157), (156), (154), (153) and (152) of recent date.

At trench 4 the geochemical survey can only be detecting geochemistry from the upper surface contexts (152), (153), (154), (155) and (158). The clear stratification of the deposit sequence indicates little sediment mixing and no soil development. Consequently, anomaly 5 is defined by recent sediment deposition. The subsurface Bronze Age mining feature is well beyond the detection of the surface survey and its location is co-incidental to anomaly 5 . The reason for anomaly 5 is unclear, but again a process of translocation of mineral elements from the surface bedrock in the upper colluvial inwashing would seem a probable interpretation, although it is possible that the sampling may have mixed material from contexts (152) with both (155) and (158) and analysed a combination of the two.

The relationship of surface to sub-surface geochemistry is further enhanced by discussion of trench 5 , which did not produce a significant identifiable geochemical anomaly from either level of analysis. This deposit sequence at trench 5 (Figure 12) revealed a prehistoric cut feature, [40], potentially a mining pit, containing two fills ((041) and (042)), and sealed by context (038), a red firm sand that produced a mid to late Iron Age date of 390 - 200 Cal BC (95.4\% probability distribution; SUERC-17841 (GU-16449)). Above this were episodes related to probable ore processing activities (contexts (019) and (045) and colluvial inwashing (contexts (018) and (046), indicating an episodic nature to the mining. This sequence is cut by [20], an interpreted modern cut, which is back filled deliberately and shortly after cutting. It is redeposited with the material that had recently been removed for creation of [020].

All the features, fill sequences and layers within trench 5 are sealed by (017), a pink fine silty sand, with abundant sub-rounded clasts. Context (032) above (038) produced a date of $1030-1220$ Cal AD (95.4\% probability distribution; SUERC-17842 (GU-16450). The geochemical survey sampled the sealing top context (017). Beneath this are a series of prehistoric mining pits and associated ore processing wastes, with a deposit sequence stretching from at least the Iron Age through to the 
Medieval. However, the stratigraphic complexity of the sequence is masked by a sealing deposit of (017), which is inwashed colluvial sand. As this was sampled, the underlying stratigraphic complexity was not realised or identified by the geochemical survey.

The relationship of the surface geochemical survey to the archaeological excavation is relatively complex. The key outcomes are summarised as:

- Trench 8 contained imported soil that is foreign to the local site-scape and was identified by geochemical anomalies 4 and 5 .

- Trench 4 contained a Bronze Age ore processing feature but this was masked from the geochemical survey by subsequent deposit build up. There is no definable relationship between the dated Bronze Age feature and the surface geochemical anomaly 5 .

- Trench 5 also contained a prehistoric cut feature with fill sequence, interpreted as episodic ore processing, which was sealed by a later Iron Age layer. However there was no corresponding geochemical anomaly in either level of analysis, demonstrating that the surface prospection had no tangible relationship to the sub-surface mining features.

- Anomalies 3 and 6 at trench 6 were heavily influenced by Fe and $Z n$ and defined a series of deposits at the surface that were related to ironworking

- Anomaly 2 at trench 10 revealed a geochemical anomaly associated with $\mathrm{Pb}, \mathrm{Ag}, \mathrm{Ba}, \mathrm{Sr}$ and $\mathrm{As}$ and can be related to a deposit rich in galena, interpreted as imported mine spoil.

- Anomaly 1 at trench 1 was related to a piece of local ore mixed into the colluvial deposits at the surface of the trench and has no tangible relationship to any archaeological feature.

\section{Discussion}

The presentation of this dataset provided two tiers of analysis that contribute to the debate of using geochemical survey within archaeological investigations. The application of a geochemical survey within a mining landscape to identify archaeological features is made more complex by naturally high geochemical loadings within the survey area. This can be further complicated by mining activities creating geochemical signatures similar to the substrate bedrock geochemistry. For example, in areas of naturally high, although variable, copper concentrations, how is an anomaly from anthropogenic copper processing recognisable? From the Complete Dataset Analysis it is clear that the positioning of the principle components was at least in part influenced by the geological substrate. The identification of geochemical signatures relating to ore sources is advantageous as the ore may be the source input into metalworking process. Conversely, in terms of identifying more discrete anthropogenic geochemical signatures, it can be argued that unless there is high inter-variable correlation from an anthropogenic signature distinct from the bedrock geology, it is unlikely to be identified through the geochemical survey.

The methodology employed was to utilise a surface geochemical survey to identify archaeological features. The underlying assumption is that the relevant archaeological contexts are at the surface, providing a suitable sample for the geochemical survey. The subsequent excavation of the ten trenches has allowed context specificity to be applied to some of the geochemical survey points and reconciliation of interpreted geochemical anomalies and sub-surface sediment stratigraphy. For example, the ironworking debris that was identified in trench 6 was contained within archaeological contexts that were at the top (surface) of the deposit sequence. Both levels of analysis identified 
geochemical anomalies at this location (anomalies 3, 6 and 7) and these were with Fe and $\mathrm{Zn}$. At this location the context specificity of the geochemical survey undoubtedly identified ironworking activity. Likewise, trench 8 was associated with anomalies 3 and 5 and these can interpreted as relating to foreign soil imported as backfill into the mining area. Again the geochemical surface survey sampled the contexts directly, namely imported soil, allowing interpretation of the geochemical anomalies. Lastly, trench 10 was associated with anomaly 2 , and this can be shown to relate to waste clay deposits from mining activity associated with a suite a metal elements ( $\mathrm{Pb}, \mathrm{Ag}, \mathrm{Ba}, \mathrm{Sr}$ and $\mathrm{As}$ ). Again these deposits outcrop at the surface and were sampled by the pXRF.

This case can be contrasted to trenches 4 and 5. Both these trenches contained prehistoric mining features. Trench 5 had no associated geochemical anomaly and trench 4 was covered by anomaly 5 . However, in both of these cases, there is no tangible relationship between the prehistoric mining features and the geochemical survey results. At trenches 4 and 5 the surface geochemical survey was sampling colluvial inwash that had formed above these archaeological features. This reinforces the issue that context specificity is essential for the interpretation of geochemical data. Anomaly 1 is a further case in point, where although colluvium was being measured at this location, it contained pieces of local bedrock-derived ore which caused the geochemical anomaly.

\section{Conclusion}

This survey looked to investigate a mining site-scape from a surface geochemical survey. The subsequent excavation results revealed a generally variable and locally complex stratigraphic sequence. The cause of the geochemical anomalies has been explored relative to the stratigraphy of the trenches. In all cases, the context specificity of the reading location has been shown to be vital in understanding the pattern of geochemical anomalies produced. This analysis has raised significant issues regarding the use of geochemical survey as an archaeological prospection tool versus its application as a tool of intra-site or intra-excavation analysis. Critically, it has demonstrated the lack of consistent relationships between sub-surface archaeological features and surface geochemistry, and the need for context specific information to interpret geochemical survey data.

The vagary of the relationship of the surface geochemical data to the subsurface features calls into question the usefulness of geochemical survey as a prospection tool. When large scale geochemical prospection is undertaken, the lack of archaeological control (are archaeological deposits being sampled), the limited penetration depth (surface collection) and the relative cost, all indicate geochemical survey is limited as an archaeological prospection tool. However, as demonstrated by this survey, when geochemical data is integrated with context specific information, useful archaeological data can be extracted. We argue that geochemical survey can add its greatest value to archaeological investigation as a tool of intra-excavation analysis, bridging the divide between prospection and excavation. As such it can provide context specific information that is correlated to human activities within that context.

Geochemical survey is ideally suited to identifying the residues from past episodes of metalworking, given the high geochemical inputs into the archaeological site formation process. However, in an area where there are naturally high concentrations of metallic elements such as copper, e.g. mining landscapes such as Alderley Edge, identifying anomalies that are anthropogenically derived will be difficult. Contrastingly, identifying geochemical anomalies produced through metalworking away 
from areas of mineralisation should be easier, such as identifying copper anomalies in sediments where copper does not naturally occur in high concentrations. In such scenarios geochemical survey has considerable potential to identify metalworking activities in the archaeological record.

In a climate where archaeologists are increasingly aware of the finite, fragile and continuously threatened and degraded archaeological resource, smaller archaeological excavations are increasingly common, especially within an academic context. Conversely, these smaller excavations are being investigated with an increasingly sophisticated barrage of scientific techniques. In this context, archaeological geochemical analysis can play an important role in maximising data extraction, providing richer narratives of past human activities and societies.

\section{Acknowledgements}

This work was funded by the National Trust. All excavation and survey work were undertaken by University of Manchester Field Archaeology Unit (now closed). All excavation data are derived from their original report (Mottershead and Wright 2008). The excavated sections used here are derived from their original work and subsequently re-interpreted and redrawn. Any mistakes or limitations presented in the excavated data lie solely in our re-use of their data. 


\section{Bibliography}

Aston, M. A., Martin, M. H. and Jackson, A. W. 1998. The potential for heavy metal soil analysis on low status archaeological sites in Shapwick, Somerset. Antiquity, 72, pp. 838-847.

Bintliff, J. L., Davies, B., Gaffney, C., Snodgrass, A. and Waters, A. 1992. Trace metal accumulations in soils on and around Ancient Settlements in Greece, in, P Spoerry (ed), Geoprospection in the Archaeological Landscape Oxbow Monograph 18, pp. 10 - 17. Oxbow Books: Oxford.

Boyd-Dawkins, W. 1876. On the Stone Mining Tools from Alderley Edge. Journal of the Anthropological Institute of Great Britain and Ireland, V, pp. 2-5.

Canti, M. and Huisman, D. J. 2015. Scientific advances in geoarchaeology during the last twenty years. Journal of Archaeological Science, 56, pp. $96-108$.

Carey, C. J., Wickstead, H. J., Juleff, G., Anderson, J. C. and Barber, M. J. 2014. Geochemical survey and metalworking: analysis of chemical residues derived from experimental non-ferrous metallurgical processes in a reconstructed roundhouse. Journal of Archaeological Science, 49, pp. $383-397$.

Carey, C. J. and Juleff, G. 2013. Geochemical survey and metalworking: a case study from Exmoor, southwest Britain, in. J Humphries and T Rehren (eds) The World of Iron, pp. 383 - 392. Archetype: London.

Carlon, C. J. 1979. The Alderley Edge Mines. John Sherratt and Son Ltd: Altringham.

Clark, A. 1997. Seeing beneath the soil. Routledge: New York.

Conway, J. 1983. An investigation of soil phosphorus distribution within occupation deposits from a Romano-British hut group. Journal of Archaeological Science, 2, pp. 117-128.

Cook, S. R., Banerjea, R. Y, Marchall, L. J., Fulford, M., Clarke, A and van Zwieten, C. 2010. Concentrations of copper, zinc and lead as indicators of hearth usage at the Roman own of Calleva Atrebatum (Silchester, Hampshire, UK). Journal of Archaeological Science, 37, pp. 871-879.

Cook, S. R., Clarke, A. S. and Fulford, M. G. 2005. Soil geochemistry and detection of early Roman precious metal and copper alloy working in the Roman town of Calleva Atrebatum (Silchester, Hampshire, UK). Journal of Archaeological Science, 32, pp. $805-812$.

Davis, L. G., Macfarlen, S. J. and Henrickson, C. N. 2012. A PXRF-based chemostratigraphy and provenience system for the Coopers Ferry site, Idaho. Journal of Archaeological Science, 39, pp. 663671.

Dirix, K., Muchez, P, Degryse, P., Mušič, B. and Poblome, J. 2013. Integrating multi-element geochemical and magnetic survey at ancient Sagalassos (Southwest Turkey): anthropogenic versus natural anomalies. Archaeological Prospection, 20, pp. $233-247$. 
Entwistle, J. Abrahams, P. W. and Dodgshon, R. A. 2000. The geoarchaeological significance and spatial variability of a range of physical and chemical soil properties from a former habitation site, Isle of Skye. Journal of Archaeological Science, 27, pp. 287 - 303.

Gaffney, C. F. 2008. Detecting trends in prospecting for the past: fifty years of geophysical survey. Archaeometry, 50, pp. 313-336.

Gaffney, C. and Gater, J. 2003. Revealing the buried past. Geophysics for archaeologists. Tempus: Stroud.

Garner A., Prag J.A.N.E., Housley R. 1993. The Alderley Edge Shovel, An Epic in three Acts. Current Archaeology, 137, pp. 172-175.

Grattan, J. P., Gilbertson, D. D. and Hunt, C. O. 2007. The local and global dimensions of metalliferous pollution derived from a reconstruction of an eight thousand year record of copper smelting and mining at a desert frontier in southern Jordan. Journal of Archaeological Science, 34, pp. 83-110.

James, P. 1999. Soil variability in the Area of an Archaeological Site near Sparta, Greece. Journal of Archaeological Science, 26, pp. 1273 - 1288.

Jenkins, D., Owen, A. \& Lewis, A. 2001. A rapid geochemical survey of the Bronze Age copper mines on the Great Orme, Llandudno, in A Millard (ed), Archaeological Science 1997. BAR International Series 939, 164-169

Knudson, K. J., Frink, L., Hoffman, B. W. and Price, D. T. 2004. Chemical characterization of Artic soils: activity area analysis in contemporary Yup'ik fish camps using ICP-AES. Journal of Archaeological Science, 31, pp. $443-456$.

Killick, D. 2015. The awkward adolescence of archaeological science. Journal of Archaeological Science, 56, pp. $242-247$.

Linderholm, J. and Lundberg, E. 1994. Chemical Characterisation of Various Archaeological Soil Samples using Main and Trace Elements determined by Inductively Coupled Plasma Atomic Emission Spectrometry. Journal of Archaeological Science, 21, pp. $303-314$.

Middleton, W. D. and Price, T. D. 1996. Identification of activity areas by multi-element characterisation of sediments from modern and archaeological house floors using inductively coupled plasma-atomic emission spectroscopy. Journal of Archaeological Science, 23, pp. 673-687.

Milek, K. B. and Roberts, H. M. 2013. Integrated geoarchaeological methods for the determination of site activity areas: a study of a Viking house in Reykjavik, Iceland. Journal of Archaeological Science, 40, pp. $1845-1865$.

Misarti, N., Fuinney, B. P. and Maschner, H. 2011. Reconstructing site organisation in the eastern Aleutian Islands, Alsaka using multi-element chemical analysis of soils. Journal of Archaeological Science, 38, pp. 1441-1455.

Mottershead, G. and Wright, J. 2008. Stormy Point, Alderley Edge, Cheshire: An Archaeological Evaluation. Unpublished Report by the University of Manchester Archaeological Unit. Manchester. 
Oonk, S., Clomp, C. P., Huisman, D. J. and Vriend, S. P. 2009. Effects of site lithology on geochemical signatures of human occupation in archaeological house plans in the Netherlands. Journal of Archaeological Science, 36, pp. 1215-1228.

Parnell, J. J., Terry, R. E. and Nelson, Z. 2002. Soil chemical analysis applied as an interpretative tool for ancient human activities in Piedras Negras, Guatemala. Journal of Archaeological Science, 29, pp. $379-404$.

Sainter, J. D. 1878. The jottings of some geological, archaeological, botanical, ornithological and zoological rambles around Macclesfield. Swinnerton \& Brown: Macclesfield.

Timberlake, S and Kidd, D. 2005 .The archaeological excavation of a Roman mine shaft and gallery ('Pot Shaft') at Engine Vein, Alderley Edge, in S Timberlake and A Prag, (eds), The Archaeology of Alderley Edge Survey, Excavation and Experiment in an Ancient Mining Landscape. BAR (British Series) 396, pp. 79 - 97. Archaeopress: Oxford.

Timberlake, S. and King, C. 2005. Archaeological excavations at Engine Vein, Alderley Edge, 1997, in S Timberlake and A Prag, (eds), The Archaeology of Alderley Edge Survey, Excavation and Experiment in an Ancient Mining Landscape. BAR (British Series) 396, pp. 33 - 57. Archaeopress: Oxford.

Torrence, R., Martinón-Torres, M. and Rehren, Th. 2015. Forty years and still growing: journal of archaeological science looks to the future. Journal of Archaeological Science, 56, pp. 1-8.

Vittori Antisari, L., Cremonini, S., Desantis, P., Calastri, C and Vianello, G. 2013. Chemical characterisation of anthro-technosols from Bronze to Middle Age in Bologna (Italy). Journal of Archaeological Science, 40, pp. $3660-3671$.

Wilson, C. A., Davidson, D. A., Cresser, M. S. 2009. An evaluation of the site specificity of soil elemental signatures for identifying and interpreting former function areas. Journal of Archaeological Science, 36, pp. $2327-2334$.

Wilson, C. A., Davidson, D. A., Cresser, M. S. 2008. Multi-element soil analysis: an assessment of its potential as an aid to archaeological interpretation. Journal of Archaeological Science, 35, pp. 412424. 


\section{Figure captions}

Figure 1: The location of the study area in the UK (A), and in relation to the mining features around Alderley Edge (B), and the site survey area with topography and base map (C).

Figure 2: Univariate graphical analysis of some of the key elements from the Complete Dataset Analysis.

Figure 3: The PCA of the Complete Dataset Analysis.

Figure 4: The spatial analysis of the PCl factor scores from the Complete Dataset Analysis.

Figure 5: The spatial analysis of the PCII factor scores from the Complete Dataset Analysis.

Figure 6: The PCA of the Sediment Only Analysis.

Figure 7: The spatial analysis of the PCI factor scores from the Sediment Only Analysis.

Figure 8: The spatial analysis of the PCII factor scores from the Sediment Only Analysis.

Figure 9: Excavated sections from trenches 1 and 10, highlighting sub-surface features, deposits and stratigraphy. Derived from original drawings by Mottershead and Wright 2008.

Figure 10: Excavated sections from trenches 6 and 8, highlighting sub-surface features, deposits and stratigraphy. Derived from original drawings by Mottershead and Wright 2008.

Figure 11: Trench 4 southwest facing section showing the prehistoric prospection pit and later colluvial inwash and backfill. Derived from original drawings by Mottershead and Wright 2008.

Figure 12: Trench 5 north-east facing section showing the relatively complex sub-surface stratigraphy and overall covering of colluvium. Derived from original drawings by Mottershead and Wright 2008. 

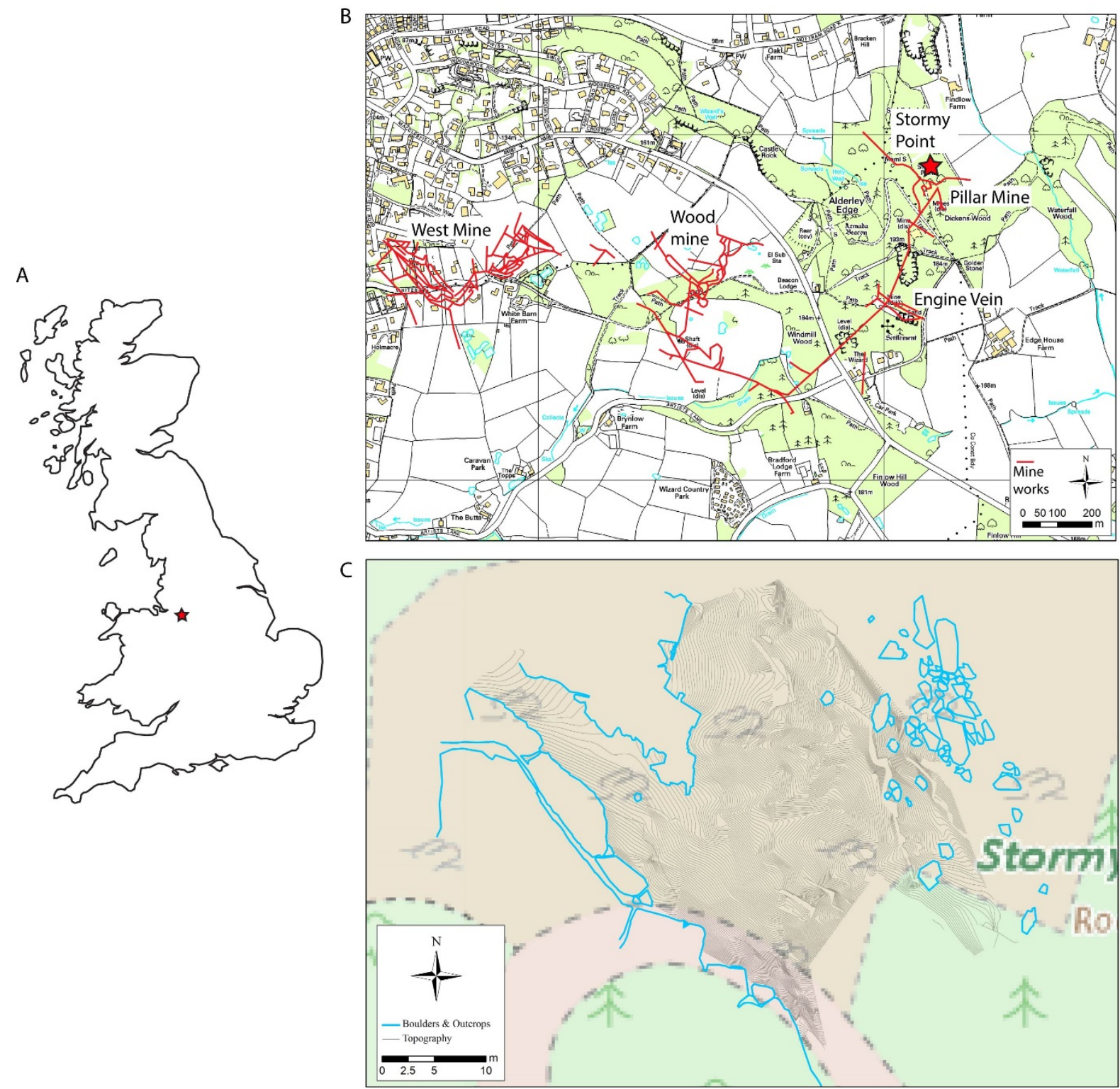

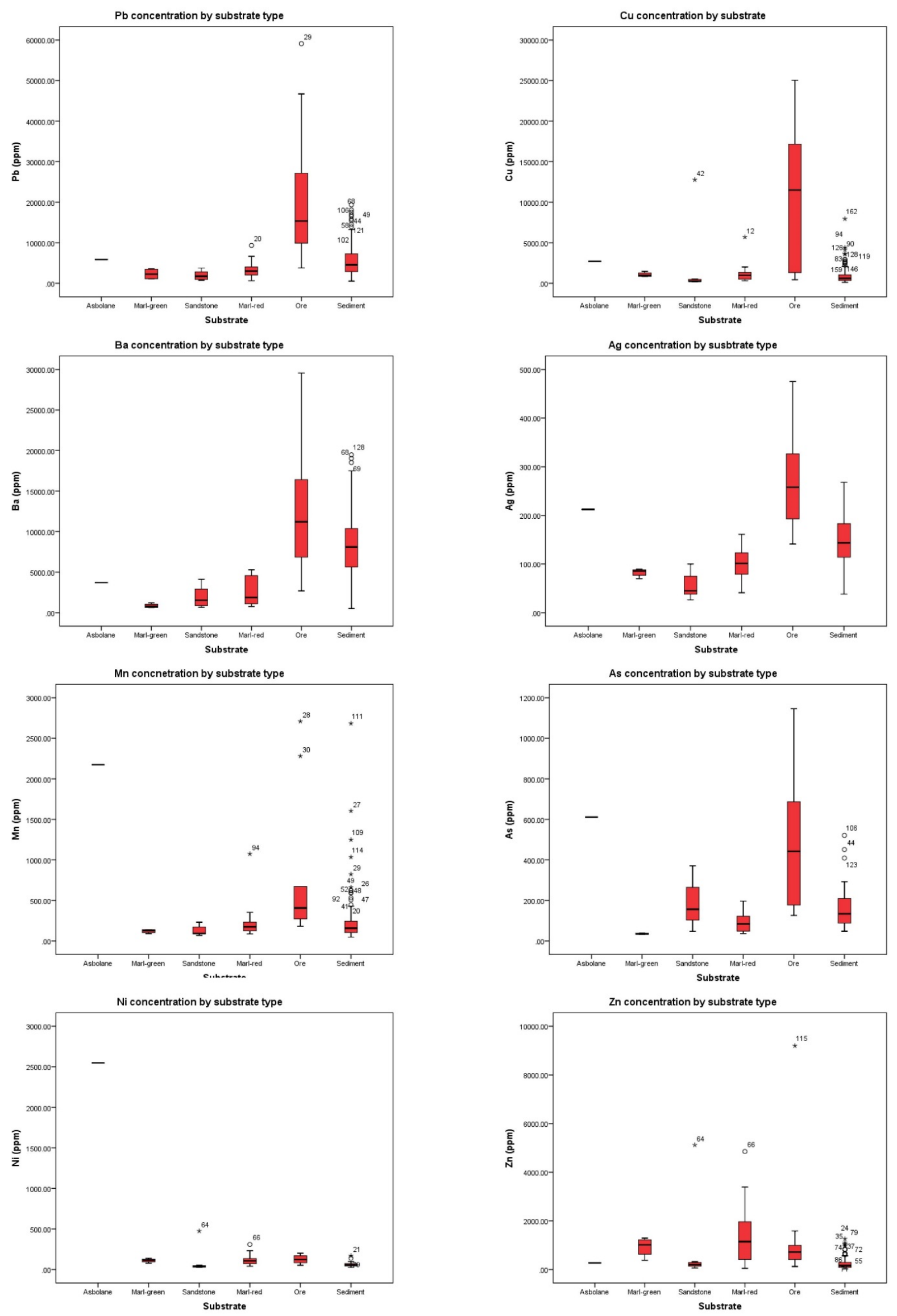
Total Variance Explained

\begin{tabular}{|c|c|c|c|c|c|c|}
\hline \multirow[b]{2}{*}{ Component } & \multicolumn{3}{|c|}{ Initial Eigenvalues } & \multicolumn{3}{|c|}{ Extraction Sums of Squared Loadings } \\
\hline & Total & $\%$ of Variance & Cumulative \% & Total & $\%$ of Variance & Cumulative \% \\
\hline 1 & 5.092 & 39.169 & 39.169 & 5.092 & 39.169 & 39.169 \\
\hline 2 & 3.298 & 25.372 & 64.541 & 3.298 & 25.372 & 64.541 \\
\hline 3 & 1.929 & 14.835 & 79.376 & 1.929 & 14.835 & 79.376 \\
\hline 4 & .895 & 6.887 & 86.263 & & & \\
\hline 5 & .647 & 4.974 & 91.237 & & & \\
\hline 6 & .416 & 3.200 & 94.437 & & & \\
\hline 7 & .237 & 1.819 & 96.256 & & & \\
\hline 8 & .182 & 1.397 & 97.653 & & & \\
\hline 9 & .097 & .747 & 98.400 & & & \\
\hline 10 & .068 & .524 & 98.924 & & & \\
\hline 11 & .064 & .496 & 99.419 & & & \\
\hline 12 & .057 & .439 & 99.858 & & & \\
\hline 13 & .018 & .142 & 100.000 & & & \\
\hline
\end{tabular}

Extraction Method: Principal Component Analysis.

Component Matrix ${ }^{\mathrm{a}}$

\begin{tabular}{|c|c|c|c|}
\hline & \multicolumn{3}{|c|}{ Component } \\
\hline & 1 & 2 & 3 \\
\hline $\mathrm{Ti}(\mathrm{ppm})$ & -.530 & .695 & -.294 \\
\hline Mn (ppm) & .129 & .647 & -.571 \\
\hline $\mathrm{Fe}(\mathrm{ppm})$ & -.592 & .659 & .216 \\
\hline $\mathrm{Ni}(\mathrm{ppm})$ & -.168 & .631 & -.650 \\
\hline $\mathrm{Cu}(\mathrm{ppm})$ & -.396 & .480 & .387 \\
\hline $\mathrm{Pb}(\mathrm{ppm})$ & .724 & .519 & .255 \\
\hline Zn (ppm) & -.688 & .419 & .484 \\
\hline $\mathrm{Ag}(\mathrm{ppm})$ & .755 & .576 & .189 \\
\hline $\mathrm{Ba}(\mathrm{ppm})$ & .895 & .222 & .271 \\
\hline $\mathrm{Rb}(\mathrm{ppm})$ & -.832 & .308 & .338 \\
\hline $\mathrm{Sr}(\mathrm{ppm})$ & .741 & .157 & .479 \\
\hline $\mathrm{Zr}(\mathrm{ppm})$ & -.491 & .018 & .377 \\
\hline As (ppm) & .639 & .623 & -.055 \\
\hline
\end{tabular}

Extraction Method: Principal Component Analysis.

a. 3 components extracted.

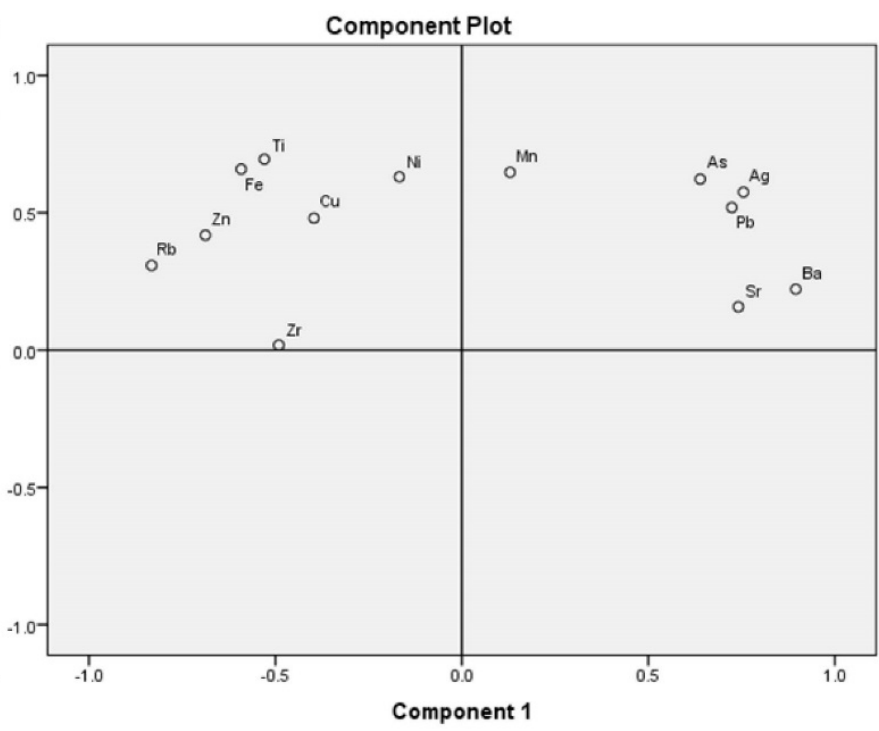



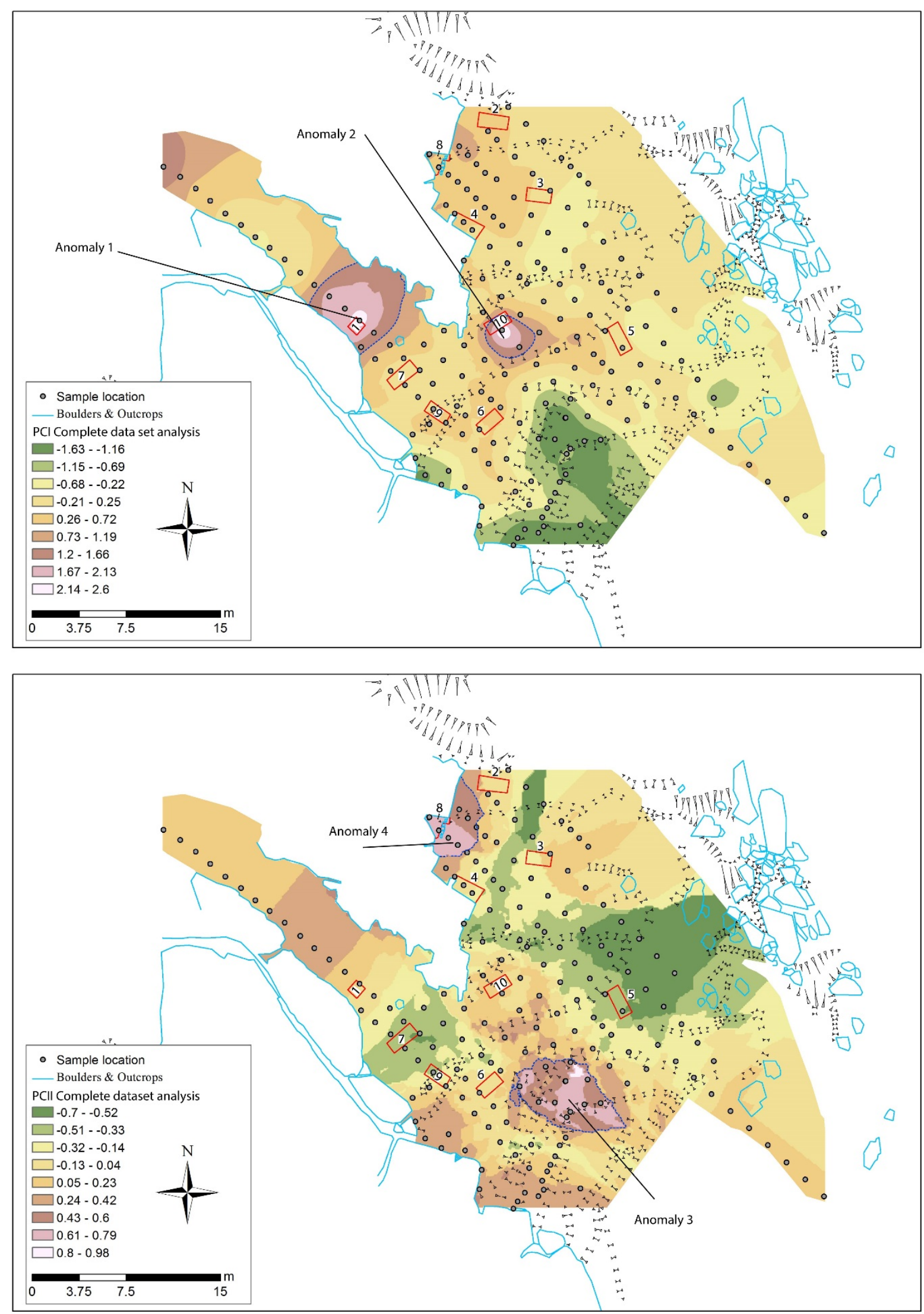
Total Variance Explained

\begin{tabular}{|l|r|r|r|r|r|r|}
\hline \multirow{2}{*}{ Component } & \multicolumn{3}{|c|}{ Initial Eigenvalues } & \multicolumn{2}{c|}{ Extraction Sums of Squared Loadings } \\
\cline { 2 - 7 } 1 & \multicolumn{1}{|c|}{ Total } & \% of Variance & Cumulative \% & Total & \% of Variance & Cumulative \% \\
\hline 2 & 3.298 & 25.369 & 25.369 & 3.298 & 25.369 & 25.369 \\
3 & 2.699 & 20.763 & 46.132 & 2.699 & 20.763 & 46.132 \\
4 & 1.871 & 14.389 & 60.521 & 1.871 & 14.389 & 60.521 \\
5 & 1.238 & 9.526 & 70.047 & 1.238 & 9.526 & 70.047 \\
6 & .885 & 6.806 & 76.853 & & & \\
7 & .657 & 5.055 & 81.908 & & & \\
8 & .569 & 4.380 & 86.288 & & & \\
9 & .534 & 4.106 & 90.394 & & & \\
10 & .434 & 3.336 & 93.730 & & & \\
11 & .337 & 2.593 & 96.323 & & & \\
12 & .263 & 2.024 & 98.347 & & & \\
13 & .155 & 1.189 & 99.536 & & & \\
\hline
\end{tabular}

Extraction Method: Principal Component Analysis.

Component Matrix ${ }^{\mathrm{a}}$

\begin{tabular}{|l|r|r|r|r|}
\hline & \multicolumn{5}{|c|}{ Component Matrix $^{\mathrm{a}}$} \\
\cline { 2 - 5 } & 1 & \multicolumn{3}{|c|}{ Component } \\
\hline $\mathrm{Ti}(\mathrm{ppm})$ & .148 & .571 & 3 & \multicolumn{1}{c|}{} \\
$\mathrm{Mn}(\mathrm{ppm})$ & .355 & -.012 & -.196 & .114 \\
$\mathrm{Fe}(\mathrm{ppm})$ & .225 & .806 & -.021 & .409 \\
$\mathrm{Ni}(\mathrm{ppm})$ & .356 & .595 & -.224 & .078 \\
$\mathrm{Cu}(\mathrm{ppm})$ & .490 & .263 & -.378 & -.391 \\
$\mathrm{~Pb}(\mathrm{ppm})$ & .731 & .158 & -.300 & -.235 \\
$\mathrm{Zn}(\mathrm{ppm})$ & .106 & .702 & -.401 & .304 \\
$\mathrm{Ag}(\mathrm{ppm})$ & .897 & -.148 & .127 & -.254 \\
$\mathrm{Ba}(\mathrm{ppm})$ & .798 & -.351 & .291 & -.050 \\
$\mathrm{Rb}(\mathrm{ppm})$ & -.277 & .569 & .454 & -.246 \\
$\mathrm{Sr}(\mathrm{ppm})$ & .739 & -.376 & .443 & -.100 \\
$\mathrm{Zr}(\mathrm{ppm})$ & .003 & .386 & .707 & -.222 \\
$\mathrm{As}(\mathrm{ppm})$ & .351 & .154 & -.111 & .180 \\
\hline
\end{tabular}

Extraction Method: Principal Component Analysis.

a. 4 components extracted.

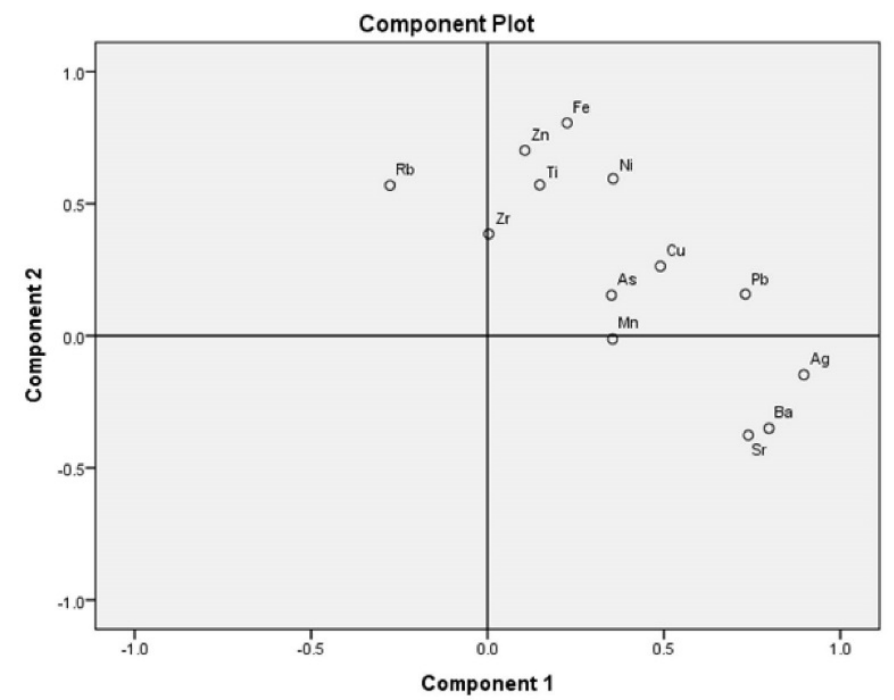



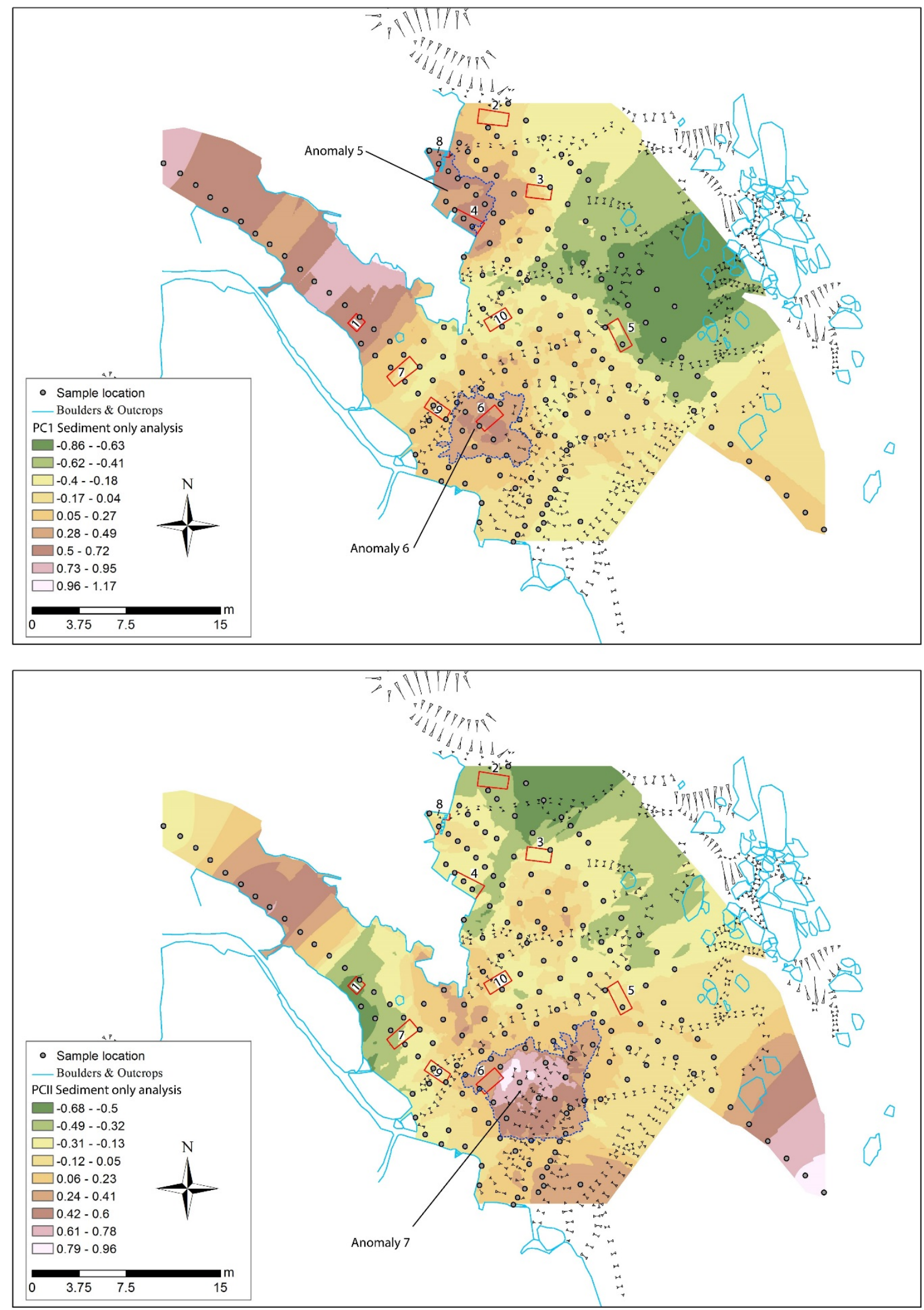


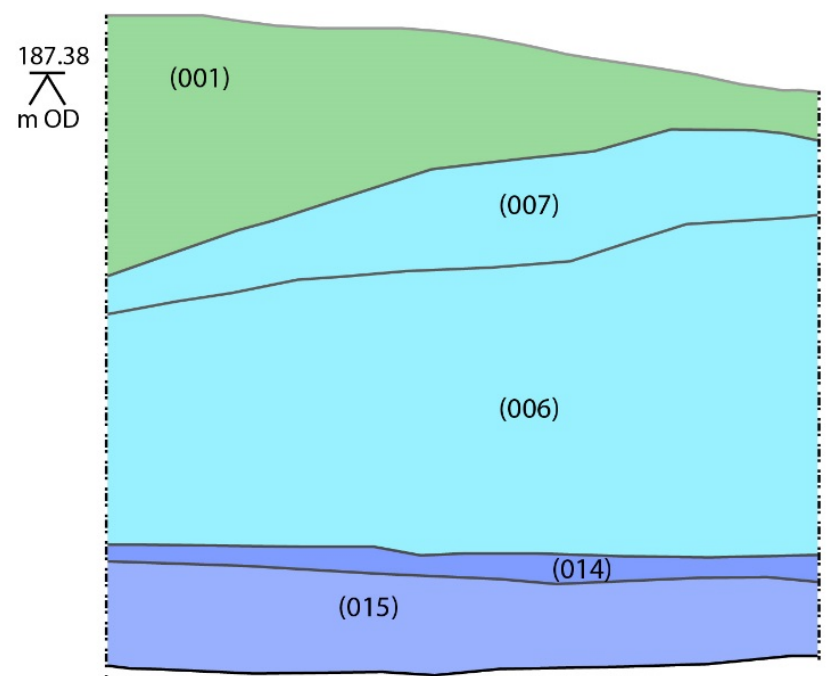

Trench 1 southeast facing section

(001) = Colluvial silty sand, with sub-rounded pebbles and sub-angular sandstone

(006) $=$ Possible mine spoil - dark brown soft sand with sub-angular sandstone and small pieces of unprocessed galena

(007) $=$ Possible mine spoil - brown silty sand with sub-angular sandstone clasts

(013) $=$ Fragmented sandstone bedrock

(014) $=$ Possible mine spoil - dark brown gritty firm sand with sub-angular sandstone, upper part of an upcast mound

(015) $=$ Possible mine spoil - light yellow brown gritty sand with sub-angular sandstone, lower part of an upcast mound

(013)

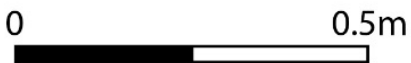

Trench 10 southeast facing section

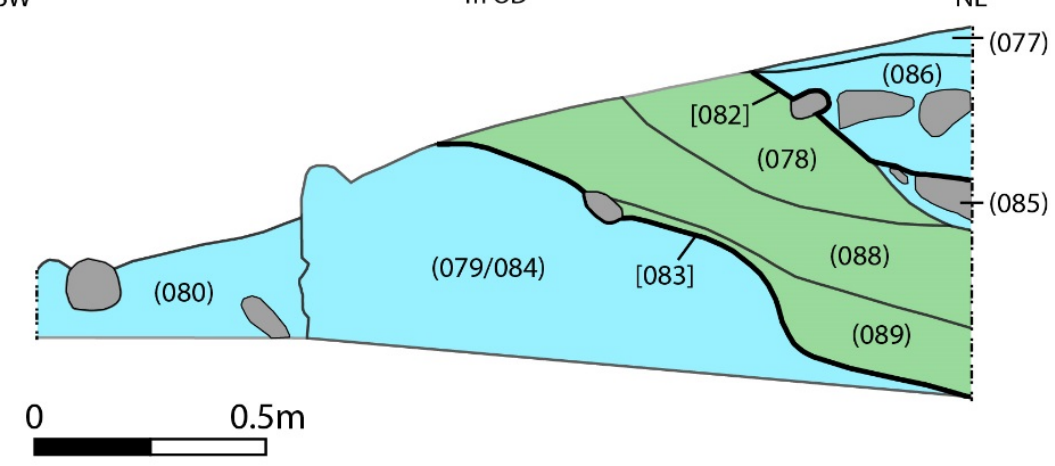

(077) $=$ Mid brownish yellow coarse sand containing small pieces of azurite and malachite

$(078)=$ Mixed orangey brown loose sand, with pockets of red silty clay and orange sand

$(079 / 084)=$ Orange brown loose sand with pockets of red silty clay and orange sand, contained galena

$(080)=$ Mid yellowish very loose sand, sub-angular fragmented sandstone, galena, malachite and azurite

[082] $=$ Possible re-cut of sub circular pit

[083] = Cut for large sub circular pit

$(085)=$ Mixed brown hard clayey sand, with sub-angular sandstone and greenish marl

(086) = Basal fill, brownish yellow sand with frequent angular sandstone, pockets of red sandy clay and galena inclusions

$(088)=$ Mixed deposit reddish orange sand, with grey silt clay lenses, colluvial inwash

(089) $=$ Mixed loose deposit of grey red and yellow sand, colluvial inwash

Stone/bedrock

Colluvial inwash deposit

Mining spoil

........ Edge of excavation

Upcast mound

\section{Context interface}

Cut 


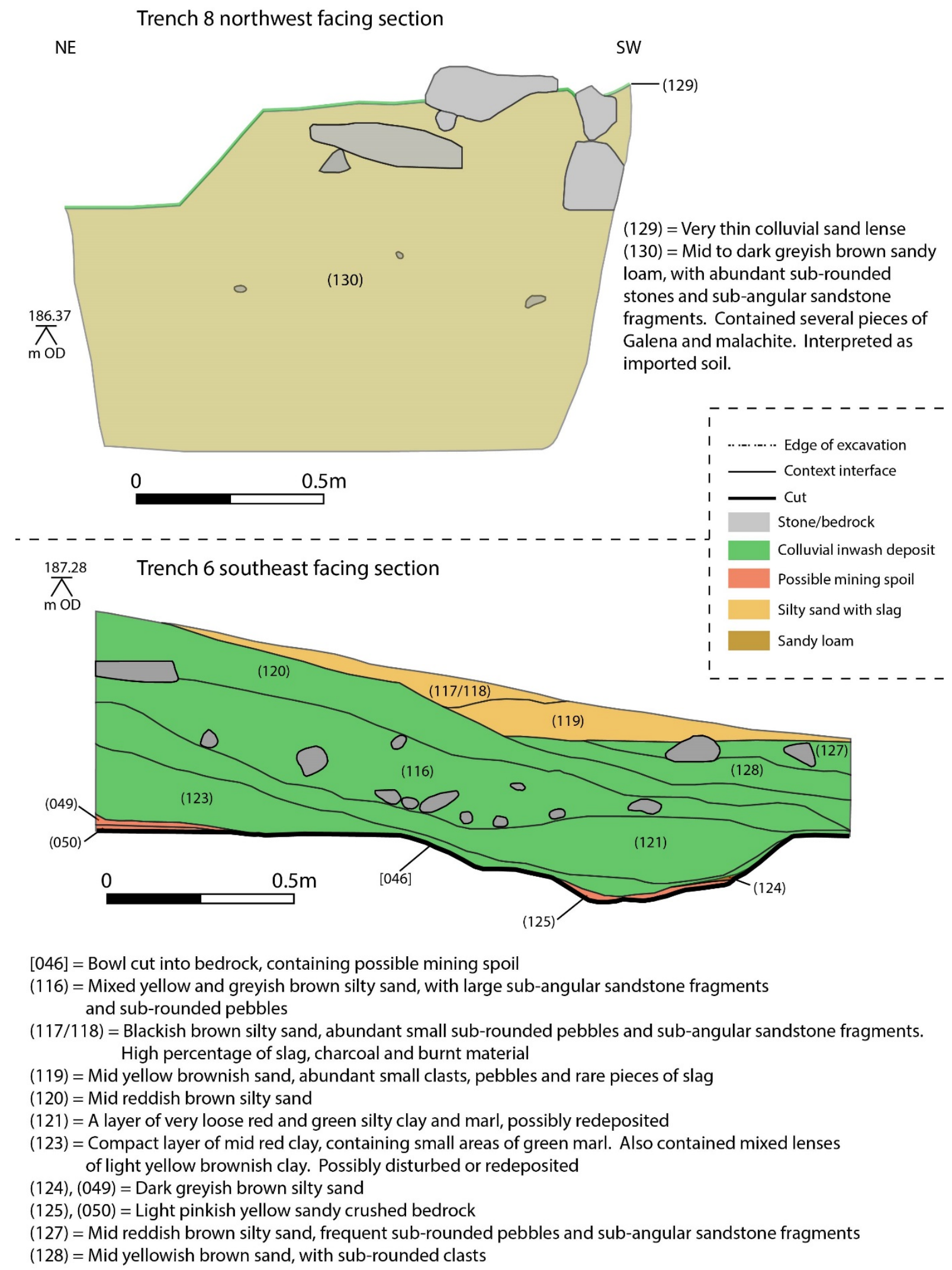




\section{Trench 4 southwest facing section}

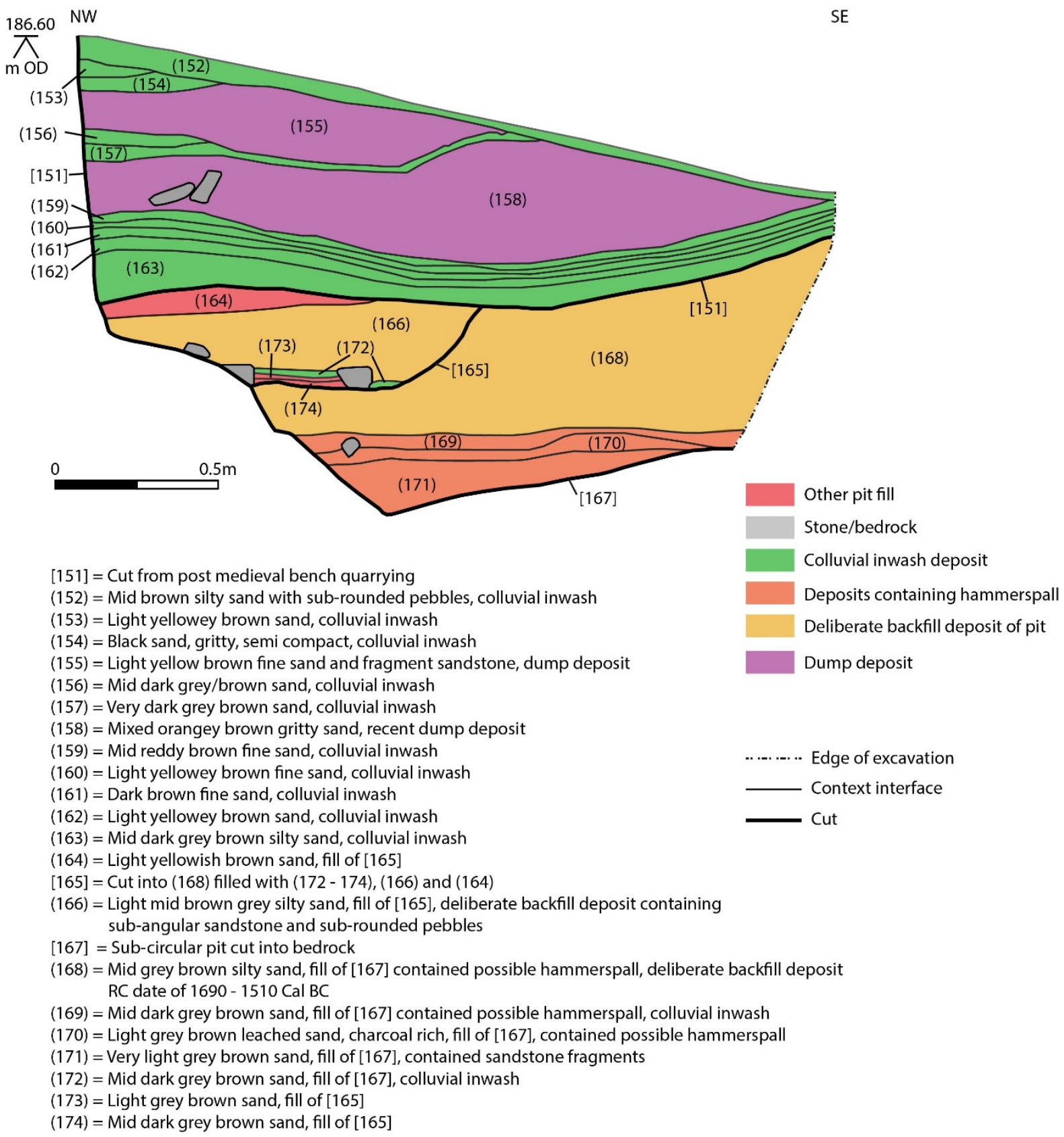




\section{Trench 5 northeast facing section}

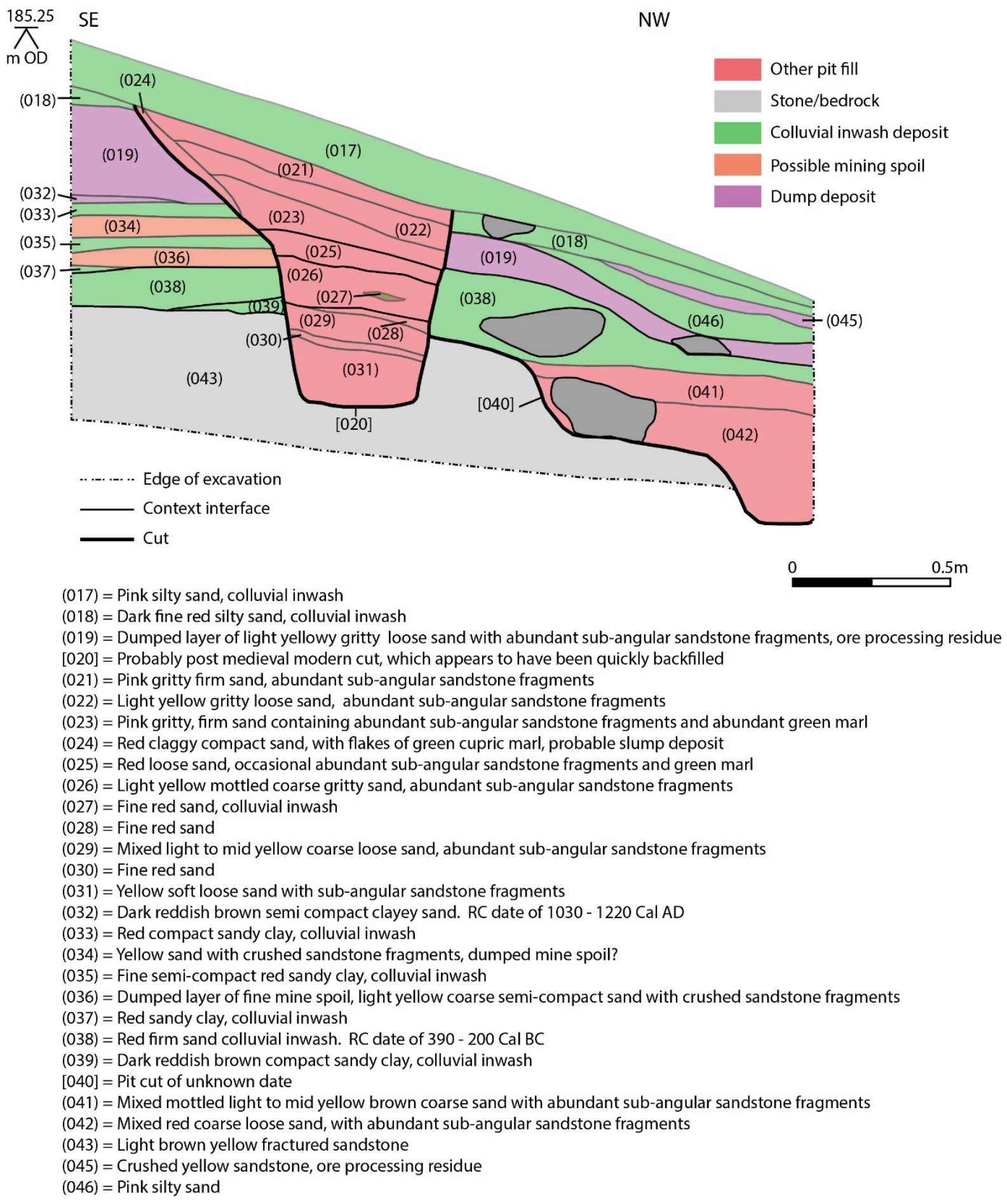

